\title{
Leaf seasonal accumulation of a 47-kDa dehydrin and changes in its cryoprotective activity in Nothofagus dombeyi (Mirb.) Blume
}

\section{Acumulación estacional de una deshidrina de 47-kDa en hojas y cambios en su actividad crioprotectora en Nothofagus dombeyi (Mirb.) Blume}

\author{
Jorge Gallardo-Cerda ${ }^{1 *}$, León A. Bravo² \& Luis J. Corcuera ${ }^{1}$ \\ ${ }^{1}$ Departamento de Botánica, Facultad de Ciencias Naturales y Oceanográficas, Universidad de Concepción, Casilla 160-C, \\ Concepción, Chile. \\ ${ }^{2}$ Laboratorio de Fisiología y Biología Molecular Vegetal, Instituto de Agroindustrias Departamento de Ciencias Agronómicas \\ y Recursos Naturales, Facultad de Ciencias Agropecuarias y Forestales, and Center of Plant, Soil Interaction and Natural \\ Resources Biotechnology, Scientific and Technological Bioresource Nucleus, Universidad de La Frontera, Casilla 54D, \\ Temuco, Chile. \\ *jgallard@udec.cl
}

\begin{abstract}
Nothofagus dombeyi (Mirb.) Blume is an evergreen tree, pioneer in habitats subject to unfavorable environmental conditions as nighttime freezing temperatures and low water content. It inhabits zones characterized by cold Winter with freezing temperature and Spring frosts reaching to $-5^{\circ} \mathrm{C}$. Furthermore, it has the capacity to maintain a functional photosynthetic apparatus at low temperatures. We postulated that $N$. dombeyi is capable to accumulate dehydrins in leaves in response to cold. Seasonal variation in dehydrins, soluble total proteins, and cryoprotective activity in vitro of protein extracts of $N$. dombeyi leaves were analyzed during the years 2004 and 2005. A dehydrin-like protein of 47-kDa was immunologically identified; this protein was present only in Winter and Spring. The highest accumulation of this protein and the maximal in vitro cryoprotective activity was found during Spring. The leaf total protein extract of this season preserved the $100 \%$ of lactate dehydrogenase (LDH) enzyme activity after 5 freeze/thaw cycles in liquid nitrogen adding $10 \mu \mathrm{g} / \mathrm{ml}$ of total proteins extract. The soluble protein concentration increased from $1.8 \mathrm{mg} / \mathrm{g}$ in Summer to $4.8 \mathrm{mg} / \mathrm{g}$ in Fall on base of fresh weight, and declined through Winter and Spring. The $47-\mathrm{kDa}$ dehydrin may be related to cold hardiness of leaf tissue in overwintering $N$. dombeyi. We conclude that cell dehydration caused by freezing is the main factor involved in the triggering of $47-\mathrm{kDa}$ dehydrin accumulation in leaves of $N$. dombeyi. The accumulation of reactive oxygen species (ROS) by oxidative stress product of high irradiance and frosts during Spring, and their role in the triggering of the 47-kDa dehydrin accumulation in leaves of $N$. dombeyi is discussed.
\end{abstract}

KEYWORDS: Evergreen, tree, old acclimation, proteins.

\section{RESUMEN}

Nothofagus dombeyi (Mirb.) Blume es un árbol siempreverde, pionero en sitios con condiciones ambientales desfavorables como baja temperatura nocturna y baja disponibilidad hídrica. Habita en zonas caracterizadas por inviernos fríos con temperaturas congelantes y heladas de primavera que pueden llegar a los $-5^{\circ} \mathrm{C}$. Además tiene la capacidad de mantener su aparato fotosintético funcional en condiciones de baja temperatura. Postulamos que $N$. dombeyi es capaz de acumular deshidrinas en sus hojas en respuesta a baja temperatura. Se analizó la variación estacional de deshidrinas, proteínas solubles totales y la actividad crioprotectora in vitro de extractos proteicos de hojas de $N$. dombeyi durante los años 2004 y 2005 . Una proteína con características de deshidrina de $47 \mathrm{kDa}$ de peso molecular fue identificada inmunológicamente en hojas, la que estuvo presente sólo en invierno y primavera. La mayor acumulación de esta proteína en las hoja y la máxima crioprotección in vitro fue encontrada durante la estación de primavera. El extracto total de proteínas de esta estación conservó el 100\% de la actividad de la enzima lactato deshidrogenasa (LDH) después de 5 ciclos de congelamiento/descongelamiento en nitrógeno líquido agregando $10 \mu \mathrm{g} / \mathrm{ml}$ de extracto total de proteínas. La concentración de proteínas solubles totales aumentó de 1,8 mg por gramo de peso fresco en verano a 4,8 mg en otoño, y disminuyó durante el invierno y la primavera. La deshidrina de 47 kDa podría estar relacionada al endurecimiento por frío del tejido foliar en individuos de $N$. dombeyi durante el invierno, aumentando su resistencia al congelamiento. Concluimos que la deshidratación celular producida por congelamiento sería el principal factor en estimular la acumulación de esta deshidrina de $47 \mathrm{kDa}$ en hojas de $N$. dombeyi. La acumulación de especies reactivas de oxígeno (ROS) por estrés oxidativo producto de la alta irradiancia y heladas durante la primavera y su papel en el gatillamiento de la acumulación de esta deshidrina de $47 \mathrm{kDa}$ en las hojas es discutida.

Palabras Clave: Siempreverdes, árbol, frío, proteínas. 


\section{INTRODUCTION}

Low temperature is one of the major environmental stresses that limit crop productivity, quality, and post-harvest life. Most temperate plants acquire chilling and freezing tolerance upon exposure to sub lethal cold stress, a process called cold acclimation. Cold acclimation in temperate woody plants is a complex phenomenon. Frost tolerance varies seasonally, increasing throughout autumn, reaching a peak in midwinter, declining during Spring, and reaching a minimum in Summer (Sakai \& Larcher 1987). The most common responses to low temperature exposure are the cellular accumulation of compatible solutes (e.g., soluble carbohydrates and proline) (Sakai \& Larcher 1987) and the accumulation of proteins, including dehydrins. Dehydrins (DHNs) are characterized by high hydrophilicity and a diverse combination of typical domains. The most notably is a 15-amino acid lys-rich consensus sequence called $\mathrm{K}$ segment that is highly conserved in all plants.

Several DHNs possess cryoprotective activity evidenced by their protection of lactate dehydrogenase (LDH) from freeze-thaw deactivation in vitro and resistance to heatinduced coagulation.

There are few studies on the function of DHNs in vivo. Some dehydrins are mainly found in embryo and endosperm as RAB18 from Arabidopsis and RAB 17 from Zea mays mature seeds related to the acquisition of desiccation tolerance in orthodox seeds (Goday et al. 1994). There is an increase in dehydrins contents in all tissues for example Arabidopsis ERD 10 and ERD 14, and in early ice nucleation zones as epidermis and vicinity of vascular bundles for example P80 from barley and in plants under stress leading to cellular dehydration such as drought, salinity and low temperature. As far as their subcellular localization, dehydrins are located in various cell compartments including mitochondria, nucleus, and vacuoles, as well as vicinity of plasma membrane and nucleus (Danyluk et al. 1998, Borovskii et al. 2000, Mueller et al. 2003). Lipid peroxidation in plant membranes is mainly caused by free radicals attack. The overexpression of CuCOR19, a dehydrin from Citrus unshiu, inhibits the oxidation of soybean liposomes; this suggested that dehydrin might have antioxidative activity (Hara et al. 2003). Many dehydrins were detected to accumulate in nucleus and even interacting with DNA. This localization indicates stabilization of chromosomes and protection of the transcriptional machinery (Carjuzaa et al. 2008). Dehydrins could help to stabilize cell structures and macromolecules during freeze imposed dehydration of the cytoplasm (Griffith et al. 1997, Danyluk et al. 1998, Bravo et al. 1999, Rinne et al. 1999, Wisniewski et al. 1999, Yu \& Griffith 2001).

The expression of dehydrins is linked to the acquisition of desiccation tolerance in seeds, pollen and anhydrobiotic plants, but many of dehydrins are induced by cold or osmotic stress, by exogenous abscisic acid, or are even expressed constitutively, e. g. dhnX from Arabidopsis thaliana. Other functions of dehydrins include molecular chaperone-like properties and protection of protein and membrane integrity (Close 1997, Wise \& Tunnacliffe 2004).

In summary, the dehydrins may not only act as chaperones or cryoprotectants, but that they also can directly reduce lipid peroxidation and protein oxidation during cold and other abiotic stresses. (Kosová et al. 2007).

There is much of information about dehydrins in herbaceous plants. In contrast information on dehydrins in woody plants is limited. Seasonal expression of dehydrins has been noted in several species including Prunus persica, Olea europea and Betula pubescens. Low temperature, water deficit, short photoperiod, and the combination of these factors are all involved in the regulation of cold acclimation woody plants. Most of the research, however, is concentrated on buds, wood or bark tissues of deciduous species and, therefore, information about evergreens is reduced (Arora et al. 1992, Wisniewski et al. 1996, 1999, Artlip et al. 1997, Rinne et al. 1998, Kontunen-Soppela \& Laine 2001, Karlson et al. 2003, Sarnighausen et al. 2004, Welling et al. 2004).

The evergreen Nothofagus dombeyi is a widespread species and can be a pioneer tree in habitats subject to high daytime irradiances and nighttime freezing temperatures. Near its southernmost limit of its distribution, is characterized by cold winters with mean air temperatures reaching $3^{\circ} \mathrm{C}$. At the end of Winter and beginning springtime events of sudden frost are very common, reaching air temperatures near $-4^{\circ} \mathrm{C}$ (Reyes et al. 2005).

$N$. dombeyi is capable to increase its leaf cold resistance by exposure to low temperature. This process of acclimation is associated to accumulation of carbohydrates and proline (Alberdi 1987, Reyes et al. 2005). The aim of this study was to determine the existence of dehydrins in leaf tissue of $N$. dombeyi, how they vary seasonally, and their contribution to freezing resistance. Our hypothesis is that dehydrins and their cryoprtective activity increase during Winter and Spring.

\section{MATERIALS AND METHODS}

Plant Material AND CHARACTERISTICS OF THE STUDY SITE Leaves from 5 individuals of 10 years old evergreen Nothofagus dombeyi were collected in the months of April, July, October and January at Katalapi Park, X Region, Chile ( $\left.41^{\circ} 31^{\prime} 7.5^{\prime \prime} \mathrm{S}, 72^{\circ} 45^{\prime} 2.2^{\prime \prime} \mathrm{W}\right)$. The samples were collected in the field, stored in liquid nitrogen, brought to the laboratory, and processed for cryoprotective assays.

Daily maxima and minima air temperatures and precipitation were recorded at the study site with a data logger LI-1400 using LI-1400-104 and LI-1400-106 sensors, respectively (Li-Cor, Lincoln, NE). 
SIMPLASTIC PROTEIN EXTRACTION AND WESTERNBLOT ASSAY Proteins from leaf tissue were extracted in phosphate buffer (100 mM sodium phosphate, $5 \mathrm{mM}$ ascorbate, $0.3 \mathrm{mM}$ triton $\mathrm{x}-100,1 \mathrm{mM}$ EDTA and 3\% PVP, $\mathrm{pH} 7.0$ ). $5 \mathrm{~g}$ frozen leaf tissue was homogenized in $25 \mathrm{ml} 100 \mathrm{mM}$ phosphate buffer ( $\mathrm{pH}$ 7.0) followed by $20 \mathrm{~min}$ shaken at $4^{\circ} \mathrm{C}$. The samples were then centrifuged at $12,000 \mathrm{~g}$ at $4^{\circ} \mathrm{C}$ for $30 \mathrm{~min}$. The resulting supernatant was collected, filtered trough $0.4 \mu \mathrm{m}$ filter and assayed for protein content by $\mathrm{RC} \mathrm{DC}^{\mathrm{TM}}$ protein assay kit BIO-RAD Laboratories (Mississauga, ON, Canada).

Proteins were resolved by $10 \%$ sodium dodecyl sulfatepolyacrylamide gel electrophoresis (SDS-PAGE) (Laemmli 1970) using a Miniprotean III electrophoresis cell (Bio-Rad, Hercules, Calif., U.S.A.) and $20 \mu \mathrm{g}$ of heat-stable proteins were loaded in each well. Following electrophoresis, the fractionated proteins were transferred onto a nitrocellulose membrane (GE Osmonics, Minnetonka, Minn., U.S.A.) by the Bio-Rad Miniprotean II system.

After an overnight blocking with 3\% nonfat dried milk in Tris buffered saline(TBS) at $4{ }^{\circ} \mathrm{C}$, the membranewas incubated for $2 \mathrm{~h}$ with an anti-dehydrin rabbit polyclonal antiserum at a 1:1000 dilution in TBS. The antiserum was raised against a consensus peptide sequence usually present at the dehydrin carboxyl terminus (TGEKKGIMDKIKEKLPGQH). After three consecutive washes for $10 \mathrm{~min}$ each in $5 \%$ TBS-Tween $20(\mathrm{v} / \mathrm{v})$, primary antiserum was detected with alkaline phosphatase-conjugated goat anti-rabbit immunoglobulin $\mathrm{G}$ (Promega, Madison, Wis., U.S.A.). The secondary antiserum was used diluted at 1:10000 in $0.5 \%$ nonfat dried milk in TBS for $90 \mathrm{~min}$. The resulting protein-antibody complex was visualized with $10 \mathrm{ml}$ of AP buffer $(100 \mathrm{mM}$ Tris- $\mathrm{HCl}$, $\mathrm{pH} 9.5,100 \mathrm{mM} \mathrm{NaCl}, 5 \mathrm{mM} \mathrm{MgCl}_{2}$ ) containing 661 of nitroblue tetrazolium and $33 \mu$ l of 5-bromo-4-chloro-3- indolylphosphate (Promega). The specificity of the dehydrin detection was confirmed by blocking the primary antiserum for $30 \mathrm{~min}$ with an equal volume of the $\mathrm{K}$ segment peptide salt $(5 \mathrm{mg} / \mathrm{ml})$ prior to the first incubation of the membranes.

\section{CRYoprotection ASSAY}

Cryprotective activity of total extracts from every season was determined using the freeze/thaw inactivation assay of LDH (EC 1.1.1.23, Type V-S from rabbit muscle, Sigma L 5132; Sigma, St. Louis MO, USA) described by Carpenter $\&$ Crowe (1988). LDH freeze/thaw cycles were performed in liquid nitrogen and room temperature, respectively.

\section{Statistical ANALYSis}

A Spearman correlation analysis was used to assess any relationship between microclimatic data and maximal values of cryoprotection in vitro of each season of years 2004 and 2005. Data from both years 2004 and 2005 was used. The normality of data was analyzed by Shapiro-Wilkes test. All statistical tests were performed with STATISTICA 6.0 (StatSoft Inc.).

\section{RESULTS}

Microclimatic measurements

Samples were taken during the years 2004 and 2005. During those years the average of daily temperature per month, at the study site, decreased from $10^{\circ} \mathrm{C}$ in March reaching $3^{\circ} \mathrm{C}$ in June. The frozen events began in April being more frequent in August with temperature around $-3^{\circ} \mathrm{C}$. The frequency of these frosts events varied both years, but the magnitude was similar (Fig. 1).

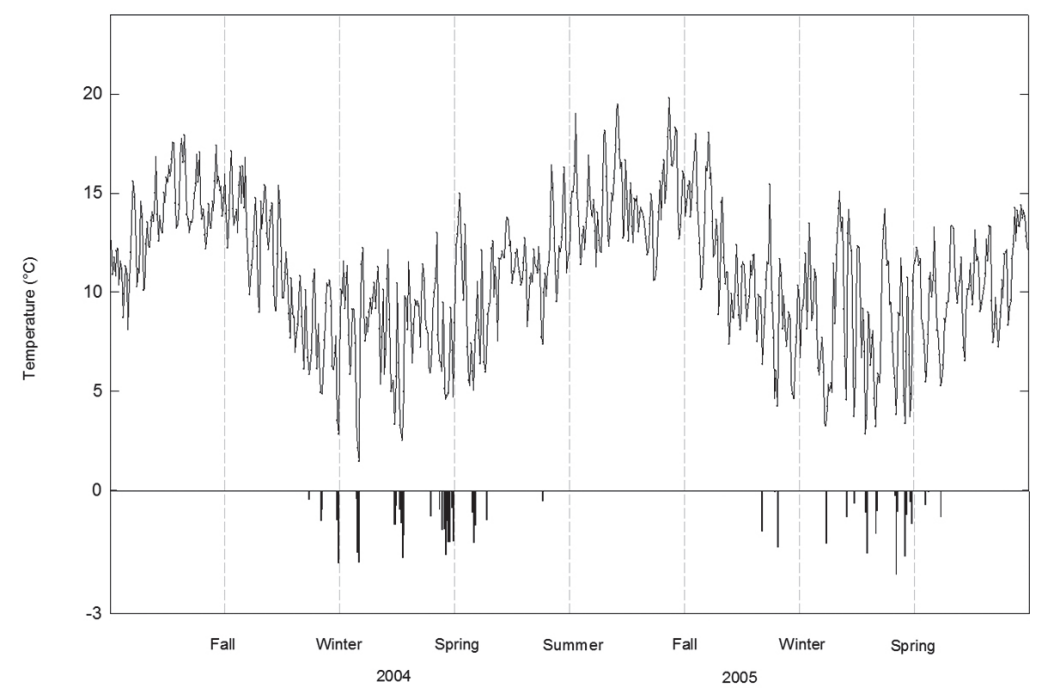

Figure 1. Annual course of temperature and frosts in Katalapi Park (X Region, Chile). Measurements were made from December 2004 to November 2005. Averages of daily minimum and below $0{ }^{\circ} \mathrm{C}$ temperature were given.

Figura 1. Curso anual de temperatura y heladas en el Parque Katalapi (X Región, Chile). Las mediciones fueron hechas desde diciembre de 2004 a noviembre de 2005. La curva representa el promedio mínimo diario y la temperatura bajo cero. 
WESTERNBLOT, PROTEIN EXTRACTION AND CRYOPROTECTION ASSAY

At least three dehydrin like proteins were found in extracts obtained from leaves of $N$. dombeyi in all seasons except Summer. A 47-kDa dehydrin was present only in Winter and Spring but absent in Fall and Summer. In leaves, the amount of this $47-\mathrm{kDa}$ dehydrin increased during Winter, reaching the maximal accumulation during Spring (Fig. 2).

The cryoprotection of the enzyme LDH in vitro by total protein extracts was grater in seasons where the 47-kDa was present than in seasons where it was absent. The highest cryoprotection was observed with Spring total protein extracts. Adding $10 \mu \mathrm{g}^{*} \mathrm{ml}^{-1}$ of total protein extract it was possible to preserve $100 \%$ of LDH activity after 5 freeze/ thaw cycles in liquid nitrogen.

The Winter total protein extract at the same concentration $\left(10 \mu \mathrm{g} \mathrm{ml}^{-1}\right)$ preserved around $80 \%$ of LDH activity in vitro at the same experimental conditions. To reach the $100 \%$ of LDH activity after 5 freeze/thaw cycles in liquid nitrogen in presence of winter total protein extract, it was needed to add $100 \mu \mathrm{g} \mathrm{ml}^{-1}$, this is ten times more concentrated of total protein than with the Spring extract (Fig. 3).

In Fall season at least 2 more dehydrins, of lower molecular weight, appeared in total extracts. However, they were not present in summer total protein extracts (Fig. 2), but both total extracts show cryoprotective activity preserving around $20 \%$ of LDH activity after 5 freeze/thaw cycles in liquid nitrogen (Fig. 3).

Total protein content in leaf tissue of $N$. dombeyi increased more than twofold from $1.8 \mathrm{mg} / \mathrm{g}$ to $4.8 \mathrm{mg} / \mathrm{g}$ of fresh weight in fall months with respect to Summer and declined through Winter and Spring (Fig. 4).

FREEZING TEMPERATURE AND CRYOPROTECTIVE ACTIVITY The cryoprotection of LDH in vitro values were positively correlated with days of frost, previous to the sampling time $(\mathrm{r}=0.83 ; \mathrm{P}=0.01)$ and inversely correlated with below zero temperature accumulated at the time of sampling $(r=-0.88$; $\mathrm{P}<0.01)$. The correlations with environmental variables related to drought (number of no rainy days and $\mathrm{mm}$ rain fallen) were not significant (Table I).

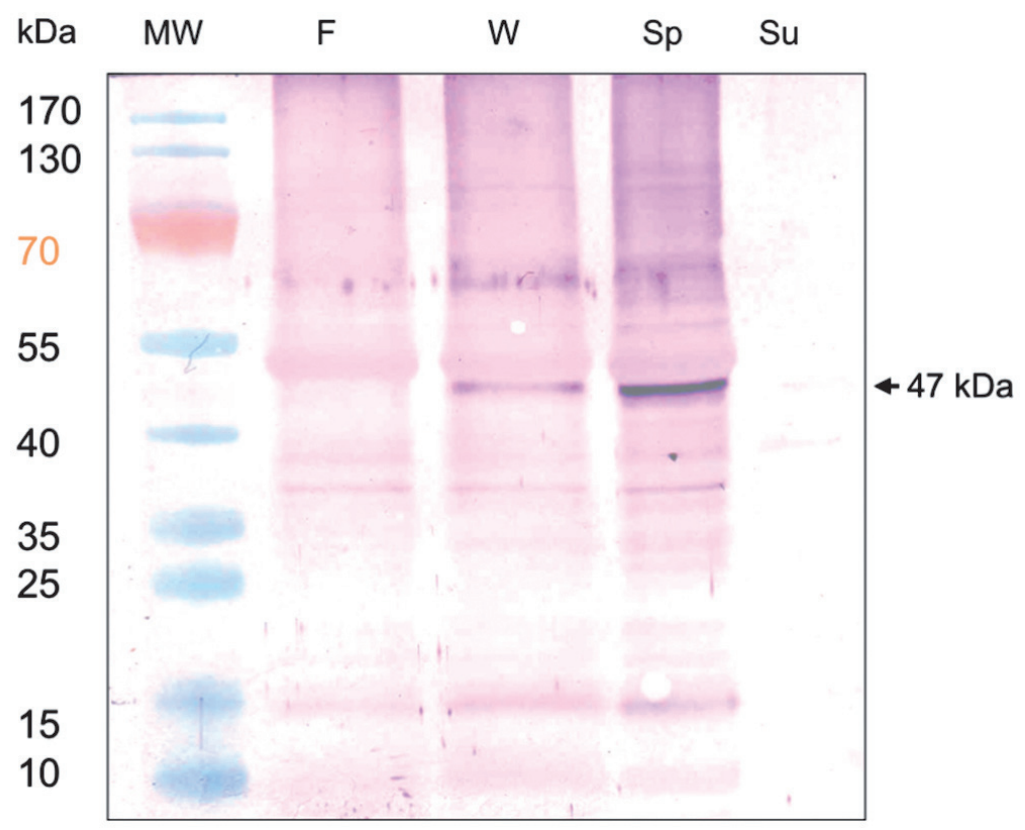

Figure 2. Inmunoblots of dehydrin protein in leaves of Nothofagus dombeyi sampled at each season. The head arrow indicates a $47 \mathrm{kDa}$ dehydrin. The letters on top indicate the seasons. F: Fall; W: Winter; SP: Spring; SU: Summer. The molecular weights of standards (MW) are indicated on the left.

Figura 2. Inmunodetección de deshidrinas en extractos proteicos totales de tejido foliar de Nothofagus dombeyi recolectado en cada estación. La flecha indica una deshidrina de $47 \mathrm{kDa}$. Las letras sobre la figura indican las estaciones del año. F: otoño; W: invierno; SP: primavera; SU: verano. Los pesos moleculares de los estándares (MW) son indicados a la izquierda. 
Dehydrine accumulation and cryoprotective activity in Nothofagus dombeyi: GALLARDO, J. ET AL.

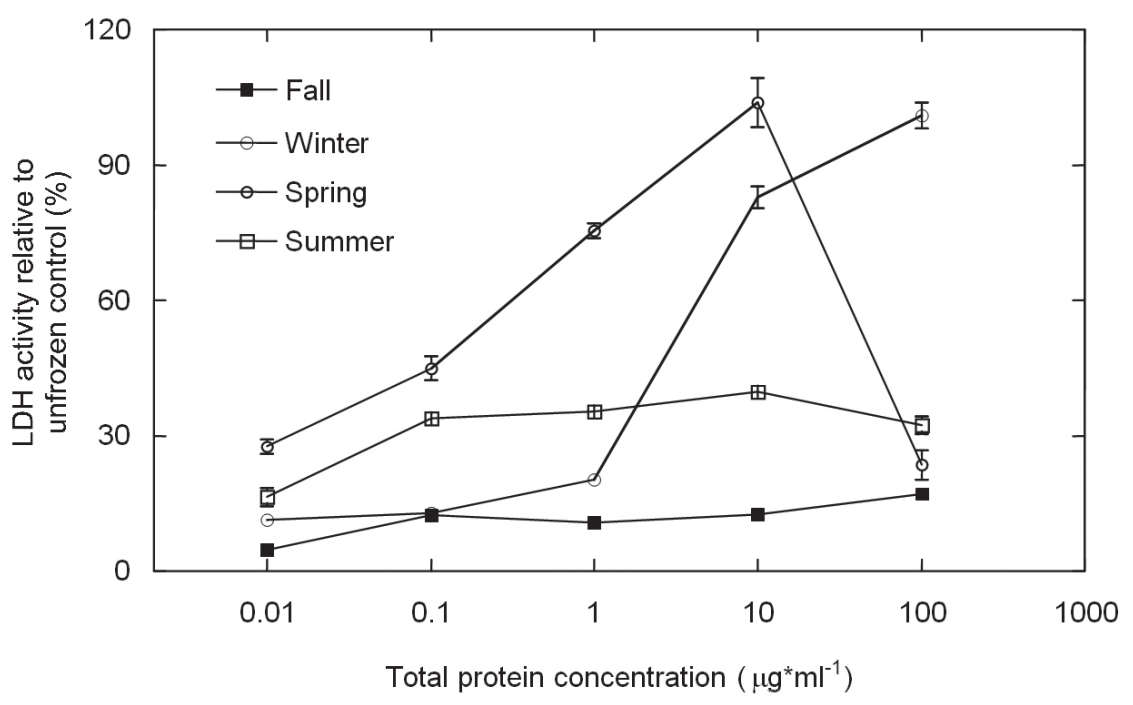

FIGURE 3. In vitro cryoprotection of lactate dehydrogenase enzyme (LDH) by the addition of different protein concentrations (log scale) from leaf extracts of Nothofagus dombeyi from different seasons. The curves show the percentage LDH activity remaining after freeze-thaw deactivation relative to unfrozen control (Mean $\pm \mathrm{SD}, \mathrm{n}=5)$.

FiguRA 3. Crioprotección in vitro de la enzima lactato deshidrogenasa (LDH) por adición de diferentes concentraciones (escala logarítmica) de extracto total de proteínas de hoja de Nothofagus dombeyi de las diferentes estaciones de año. La curva muestra el porcentaje de actividad remanente de la enzima LDH, relativa a un control no congelado, después de su desactivación por congelamiento/descongelamiento (Promedio \pm DS. $n=5$ ).

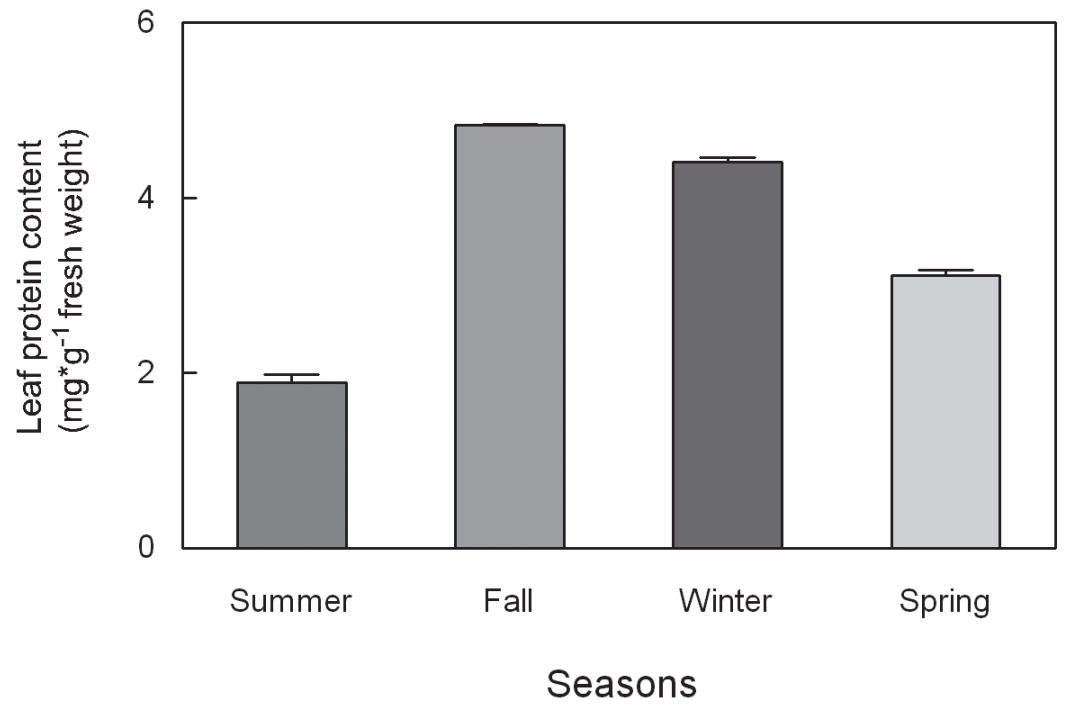

Figure 4. Seasonal changes in the amount of total protein per gram of fresh weigh in leaf tissue of 10 years old evergreen Nothofagus dombeyi trees. The bars represent the means of 5 individuals $\pm 1 \mathrm{SD}$.

Figura 4. Cambio estacional en la cantidad de proteina total por gramo de peso fresco en tejido foliar de individuos de 10 años de edad de Nothofagus dombeyi. Las barras representan el promedio de 5 individuos \pm 1 DS. 
TABLE I. Spearman correlation coefficients ( $\mathrm{r}$ ) of cryoprotection of total protein extracts from Nothofagus dombeyi leaves and microclimatic conditions recorded at Katalapi Park $(n=8)$.

TABLA I. Coeficiente de correlación de Spearman ( r ) de la crioprotección de extractos proteicos totales de hojas de Nothofagus dombeyi y condiciones microclimáticas registradas en el Parque Katalapi $(n=8)$.

\begin{tabular}{|c|c|c|c|c|}
\hline & DAYS OF FROST & $\begin{array}{l}\text { BELOW } 0{ }^{\circ} \mathrm{C} \\
\text { ACCUMULATED }\end{array}$ & NON RAINY DAYS & RaIN \\
\hline \multicolumn{5}{|c|}{ Highest cryoprotection } \\
\hline Spearman $r$ & 0,8383 & $-0,8862$ & $-0,1446$ & 0,1796 \\
\hline$P$ value & $0,0154^{*}$ & $0,0072 * *$ & $0,7520 \mathrm{~ns}$ & $0,6646 \mathrm{~ns}$ \\
\hline
\end{tabular}

ns: Not significant; * and **: Significant $\mathrm{P}<0.05$ and $\mathrm{P}<0.01$ respectively. ns: No significativo; * $\mathrm{y} * *$ : Significativo $\mathrm{P}<0.05$ y $\mathrm{P}<0.01$ respectivamente.

\section{DISCUSSION}

The accumulation of dehydrins has been described as an adaptation process by which many plants from temperate zones increase their freezing tolerance after being exposed to low non-freezing temperature and short photoperiod. This process is triggered by short photoperiod, water deficit, and low temperature (Huner et al. 1998, Kontunen-Sopela \& Laine 2001, Li et al. 2003). The combination of these factors is involved in the regulation of cold acclimation in woody plants. Our results show that $N$. dombeyi seasonally accumulate several dehydrins but $47-\mathrm{kDa}$ dehydrin vary dramatically (Fig. 2). The accumulation of dehydrins has been described as a feature of the cold acclimation process in plants. Individuals of $N$. dombeyi living in Katalapi Park began to accumulate the $47-\mathrm{kDa}$ dehydrin in Winter and showed the maximal accumulation in Spring when the photoperiod is longer and air temperature begins to rise. The accumulation of the $47-\mathrm{kDa}$ dehydrin is consistent with the cryoprotection level of total protein extracts.

The maximal cryoprotection was found in Spring. This level of cryoprotection was positively correlated with the number of days of accumulated frosts before sampling $(\mathrm{r}=$ 0.83 ) and inversely correlated with accumulated below zero degrees $(r=-0.88)$. There is a conceptual consensus that freezing of extracellular water induces cellular dehydration as a result of disequilibrated chemical potential between cellular water and the ice crystals in the apoplast (Levitt 1980, Kontunen-Soppela \& Laine 2001) concluded that the highest variation in dehydrin accumulation is found in tissues under cellular dehydration. The individuals of $N$. dombeyi living at Katalapi Park were subjected to Spring frosts. These Spring frosts fluctuated between $-3^{\circ} \mathrm{C}$ and - $5^{\circ} \mathrm{C}$ being more frequent in September. This environmental condition and the resultant cellular dehydration could be an important clue of regulation for synthesis and accumulation of the 47-kDa dehydrin and acquisition of freezing tolerance in N. dombeyi.

Other factor involved in the maximal accumulation of the 47-KDa dehydrin in Spring could be the raise in metabolic activity and sprouting of buds. Perennial plants, such as $N$. dombeyi, distinguish themselves from other plants in their ability to suspend and resume growth recurrently in response to environmental, and often seasonal, conditions. Reyes et al. (2005) measured ETRr and $\mathrm{qP}$ in $N$. dombeyi during the four seasons at the same place obtaining higher values of both parameters in Spring than in Winter. The reactivation of photochemical activity during Spring suggests that gas exchange increased. Concomitantly evapotranspiration must have increased. This could lead to dehydration of leaf tissue and cell dehydration.

The accumulation of $\mathrm{CuCOR} 15$ en Citrus unshiu is enhanced by cold stress and has metal-binding activity (Hara et al. 2005). This activity is associated with its antioxidative activity since free metal ions present an important catalytic agent for radical formation in the cells (Kosová et al. 2007). Probably the accumulation of $47 \mathrm{kDa}$ dehydrin play an important role as a scavenger of ROS in individuals living at Katalapi Park where is possible to find two ideal conditions to production of oxidative stress during Spring, low temperatures and high irradiances.

\section{CONCLUSIONS}

In conclusion, we have shown the seasonal variation of a 47-kDa dehydrin like protein accumulations in leaf tissue of 
$N$. dombeyi. The maximal accumulation of $47-\mathrm{kDa}$ dehydrin and the maximal cryoprotection in vitro was observed in Spring.

We propose that the accumulation of this 47-kDa dehydrin is associated to cellular dehydration in response to spring frosts and oxidative stress produced by low temperature and high irradiances during Spring.

We have not determined if the seasonal changes of metabolism is an important factor contributing to freezing tolerance of this species, more experiment are necessary.

\section{ACKNOWLEDGMENTS}

This research was supported by FONDECYT 1030663. JG was financed by a doctoral fellowship granted by CONICYT.

\section{REFERENCES}

Alberdi, M. 1987. Ecofisiología de especies chilenas del género Nothofagus. Bosque 8: 77-84.

Arora, R., M.E. WisniewsKi \& R. Scorza. 1992. Cold acclimation in genetically related (sibling) deciduous and evergreen peach (Prunus persica [L.] Batsch) I. Seasonal changes in cold hardiness and polypeptides of bark and xylem tissues. Plant Physiology 99: 1562-1568.

Artlip, T.S., A.M. Callahan, C.L. Basset \& M.E. Wisniewski. 1997. Seasonal expression of a dehydrin gene in sibling deciduous and evergreen genotypes of peach (Prunus persica [L.] Batsch). Plant Molecular Biology 33: 61-70.

Borovskit, G.B., I.V. Stupnikova, A.I. Antipina, C.A. Downs \& V.K. VoInikov. 2000. Accumulation of dehydrin-like proteins in the mitochondria of cold-treated plants. Journal of Plant Physiology 156: 797-800.

Bravo, L.A., T.J. Close, L.J. Corcuera \& C.L. Guy. 1999. Characterization of an $80-\mathrm{kDa}$ dehydrin-like protein in barley responsive to cold acclimation. Physiologia Plantarum 106: 177-183.

Carjuzaa, P., M. Castellion, A.J. Distefano, M. del Vas \& S. MaldonAdo. 2008. Detection and subcellular localization of dehydrin-like proteins in quinoa (Chenopodium quinoa Willd.) embryos. Protoplasma 233: 149-156.

Carpenter, J.F. \& J.H. Crowe. 1988. The mechanism of cryoprotection of proteins by solutes. Cryobiology 25:244255.

Close, T.J. 1997. Dehydrins: A commonality in the response of plants to dehydration and low temperature. Physiologia Plantarum 100: 291-296.

Danyluk, J., A. Perron, M. Houde, A. Limin, B. Fowler, N. Benhamou \& F. Sarhan. 1998. Accumulation of an acidic dehydrin in the vicinity of the plasma membrane during cold acclimation of wheat. Plant Cell 10: 623-638

Goday, A., A.B. Jensen, F.A. Culianezmacia, M.M. Alba, M. Figueras, J. Serratosa, M. Torrent \& M. Pages. 1994. The maize abscisic acid-responsive protein RAB17 is located in the nucleus and interacts with nuclear-localization signals.
Plant Cell 6: 351-360.

Griffith, M., M. Antikainen, W.C. Hon, K. Pihakaski-Maunsbach, X.M. Yu, J.U. Chun \& D.S.C. YANG. 1997. Antifreeze proteins in winter rye. Physiologia Plantarum 100: 327332.

Hara M., M. Fujinaga \& T. Kuboi. 2005. Metal binding by citrus dehydrin with histidine-rich domains. Journal of Experimental Botany 56: 2695-2703.

Hara, M., S. Terashima, T. Fukaya \& T. Kuboi. 2003. Enhancement of cold tolerance and inhibition of lipid peroxidation by citrus dehydrin in transgenic tobacco. Planta 217: 290298.

Huner, N.P.A., G. ÖQuist \& F. SARhan. 1998. Energy balance and acclimation to light and cold. Trends in Plant Science 3 (6): 224-230.

Karlson, D.T., Y. Zeng, V.E. Stirm, R.J. Joly \& E.N. Ashworth. 2003. Photoperiod regulation of a $24-\mathrm{kD}$ dehydrin-like protein in red osier dogwood (Cornus sericea L.) in relation to freeze-tolerance. Plant Cell Physiology 44: 25-34.

Kontunen-Soppela, S. \& K. Laine. 2001. Seasonal fluctuations of dehydrins is related to osmotic status in Scots pine seedlings. Trees Structure and Function 15: 425-430.

Kosová, K., P. Vitamvas \& I.T. Prasil. 2007. The role of dehydrins in plant response to cold. Biologia Plantarum 51: 601617.

LAEMLI, U.K. 1970. Cleavage of structural proteins during the assembly of the head of bacteriophage T4. Nature 227: 680-685.

LeVITT, J. 1980. Responses of plants to environmental stresses. Vol. I. Chilling, freezing and high temperature stresses. Academic Press, San Francisco, CA, 497 pp.

Li, C., O. Junttila, A. Ernstsen, P. Heino \& E.T. Palva. 2003. Photoperiodic control of growth, cold acclimation and dormancy development in silver birch (Betula pendula) ecotypes. Physiologia Plantarum 117:206-212.

Mueller, J.K., S.A. Heckathorn \& D. Fernando. 2003. Identification of a chloroplast dehydrin in leaves of mature plants. International Journal of Plant Sciences 164: 535542.

Reyes, M., M. Alberdi, F. Piper, L.A. Bravo \& L.J. Corcuera. 2005. Low temperature responses of Nothofagus dombeyi and Nothofagus nitida, two evergreen species from south central Chile. Tree Physiology 25: 1389-1398.

Rinne, P., A. Welling \& P. Kaikuranta. 1998. Onset of freezing tolerance in birch (Betula pubescens Ehrh.) involves LEA proteins and osmoregulation and is impaired in an ABAdeficient genotype. Plant Cell Environment 21: 601-611.

Rinne, P.L.H., P.L.M. KaIKuRANTA, L.H.W. van DER Plas \& C. van DER SCHOот. 1999. Dehydrins in cold-acclimated apices of birch (Betula pubescens Ehrh.): production, localization and potential role in rescuing enzyme function during dehydration. Planta 209: 377-388.

SAKAI, A. \& W. LARCHER. 1987. Frost survival of plants. Responses and adaptation to freezing stress. Springer-Verlag, Berlin, $321 \mathrm{pp}$.

Sarnighausen, E, D.T. Karlson, Y. Zeng, P.B. Goldsbrough, K.G. Raghothama \& E.N. Ashworth. 2004. Characterization of a novel YnSKn class of dehydrin-like cDNAs from cold acclimated red osier dogwood (Cornus sericea L.) xylem. Journal Crop Improvement 10: 17-35. 
Welling, A., P. Rinne, A. Vihera-Aarnio, S. Kontunen-Soppela, P. Heino \& E.T. Palva. 2004. Photoperiod and temperature differentially regulate the expression of two dehydrin genes during overwintering of birch (Betula pubescens Ehrh.). Journal of Experimental Botany 55: 507-516.

Wise, M. J. \& A. Tunnacliffe. 2004. POPP the question: what do LEA proteins do? Trends Plant Science 9: 13-17.

Wisniewski, M., T.J. Close., T. Artlip., R. Arora. 1996. Seasonal patterns of dehydrins and $70-\mathrm{kDa}$ heat-shock proteins in bark tissues of eight species of woody plants. Physiologia
Plantarum 96: 496-505.

Wisniewsi, M., R. Webb, R. Balsamo, T.J. Close, X.M. Yu \& M. GRIfFIth. 1999. Purification, immunolocalization, cryoprotective, and antifreeze activity of PCA60: A dehydrin from peach (Prunus persica). Physiologia Plantarum 105: 600-608.

YU, X.M. \& M. GRIFFITH. 2001. Winter rye antifreeze activity increases in response to cold and drought, but not abscisic acid. Physiologia Plantarum 112: 78-86.

Recibido: 08.07.11

Aceptado: 28.09.11 